\title{
Land-Use Change Analysis of National Southern Cross Road Route Development in Bantul Regency
}

\author{
Utia Kafafa $^{1 *}$, Rika Harini $^{1}$ \\ ${ }^{1}$ Department of Environmental Geography, Faculty of Geography, Universitas Gadjah Mada, Indonesia
}

\begin{abstract}
The National Southern Cross Road Route well known as Jalan Jalur Lintas Selatan (JJLS) in Indonesia. The segment which crosses Bantul Regency has $16.65 \mathrm{~km}$ long. The development of JJLS will have various kinds of impacts on the community around the road infrastructure. This study wants to know how the impact of the development that saw from the spatial dynamics of land-use change. The study area is located in Poncosari, Gadingsari, Srigading, Tirtohargo, and Parangtritis Village. We process the data using the map overlay technique then analyze it with quantitative descriptive. The results of this study are the development of JJLS in Bantul Regency has not significantly affected the land-use changes. It is evident from the location of the land-use change which is far from the road and tends to be disheveled. The Landuse changes that occur do not form a specific pattern such as the pattern of conversion of agricultural land into non-agricultural land. The less significant changes in land use are caused by the condition of the JJLS which is not yet fully connected. Moreover, the status of land ownership around JJLS is Sultan Ground so a special permit is needed if the community wants to use the land.
\end{abstract}

\section{Introduction}

Infrastructure development aims to realize balanced inter-regional and equitable distribution of development results [1]. The National Southern Cross Road Route well known as Jalan Jalur Lintas Selatan (JJLS) in Indonesia. It is a national road construction program that connects five provinces, namely East Java, DIY, Central Java, West Java, and Banten. The Southern Cross Road (JJLS) The development of JJLS passes through the coastal areas of the Daerah Istimewa Yogyakarta (DIY), namely in the Kulonprogo, Bantul, and Gunungkidul Regency.

The development of JJLS is in line with the DIY government's agenda to develop coastal areas with equal distribution of accessibility by the paradigm of Among Tani Dagang Layar [2]. This new paradigm will improve people's welfare with development from land to maritime [3]. Jalan Jalur Lintas Selatan (JJLS) crosses Bantul Regency for $16.65 \mathrm{~km}$. This area is strategic because it connects Kulonprogo and Gunungkidul Regency. The area around JJLS is designated for cultivation areas such as trade and services, food crop agriculture, and settlements.

The JJLS development process will certainly have various kinds of impacts on the lives of the people around the road infrastructure. Infrastructure such as roads can play a positive role in development, especially economic growth and can create new jobs for the surrounding community [4]. Road infrastructure plays an important role by providing mobility for the efficient movement of people, goods, and services [5].
In addition to the various positive impacts that can be felt, negative impacts will also appear as side effects of development [6]. Road construction can provide considerable economic and social benefits. However, if poorly planned or executed, such projects can lead to various problems such as serious cost overruns, corruption, environmental damage, and social and political conflicts [7].

The negative impacts of infrastructure development include reduced productive agricultural land, reduction in green open land, and damage to the environment around the construction of road infrastructure [8]. The construction of roads in the research location has displaced several productive agricultural areas. Changes in land use will trigger socio-economic changes in the community along with changes in adaptation patterns in meeting the needs of life.

This research wants to know how the impact of this development is seen from the spatial dynamics of landuse change. The spatial approach in this study is expected to be able to identify and analyze areas around development that are experiencing rapid growth or vice versa. The practical benefits of this research are expected to provide a spatial description of the impact of JJLS development in Bantul Regency and can be used as evaluation material to formulate development policies for the government.

\section{Methods}

\footnotetext{
* Corresponding author: utiakafafa@mail.ugm.ac.id
} 


\subsection{Location}

This research is located along with the JJLS development in Bantul Regency. The locations include Poncosari Village which is part of the administrative area of Srandakan District, Gadingsari and Srigading Village which is part of the Sanden District administrative area, and Tirtohargo and Parangtritis Village which are part of the Kretek District administrative area. The reason for choosing the location was because the area experienced a direct impact from the JJLS development. Fig. 1. shows the location of the research.

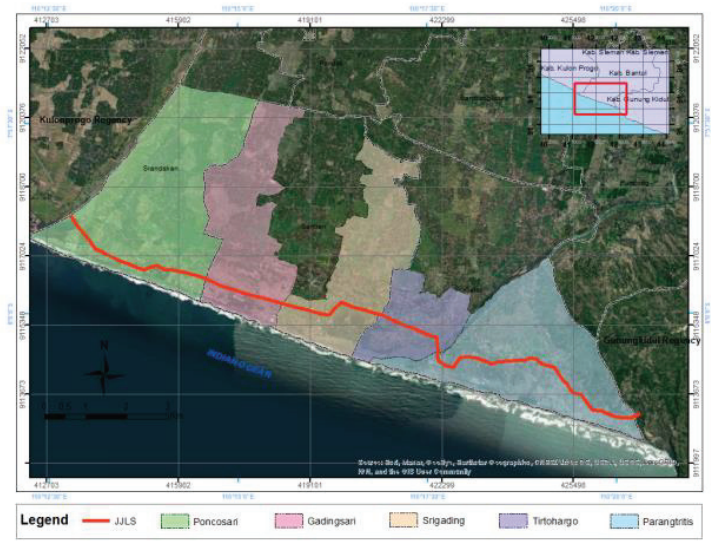

Fig. 1. Map of Research Location.

\subsection{Data}

Satellite images are recorded images of the earth's surface obtained from satellite media [9]. Interpretation of satellite images is an activity of analyzing and identifying objects recorded in the image. This study uses the interpretation of Google Earth imagery in 2013 and 2020 to determine the spatial dynamics of land-use changes that occur around the JJLS development. The year was chosen to represent the year before and after road construction.

\subsection{Data Processing}

Processing of land-use change is carried out using the ArcMap software application. Land-use change is identified through an overlay of the initial year's land use map (2013) and the final year's land use map (2020). Map overlay process can be seen in Fig.2. The next step is calculating the percentage of land-use change area. The processing result data then presented with a table of changes in the land-use area and a map of changes in land use around JJLS. Field observations were also carried out to validate the land use map.

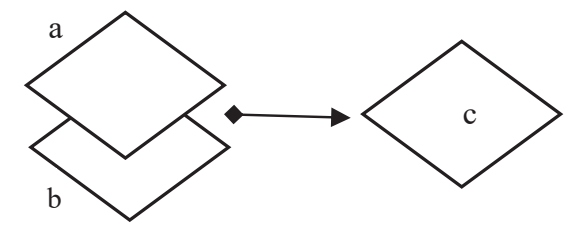

Fig. 2. (a) Land-use map in 2013, (b) land-use map in 2020, (c) Map of land-use change.

\subsection{Data Analysis}

Overall, this research uses a descriptive analysis. Descriptive analysis is an analysis that describes the general state of the data. This analysis includes several things such as frequency distribution, measurement of central tendency, and measurement of variability [10]. The analysis process in this research is divided into map overlay analysis and quantitative descriptive analysis. The map overlay analysis describes changes in the types and percentage of land use that occurred in 2013 and 2020 for each area passed by JJLS.

\section{Result and Discussions}

\subsection{Land-use change in Poncosari Village}

Based on the calculation results, the land-use in Poncosari Village has an area of 1286 Ha. From Table 1., we know that several types of land use have increased and some have decreased during 2013-2020. Mixed garden area shrank by $2 \%$ and open land area shrank by $7 \%$. Agricultural land has increased by $2 \%$, settlements also increased by $2 \%$, and bodies of water increased by $4 \%$.

Table 1. Percentage of the land-use area in Poncosari Village.

\begin{tabular}{|c|c|c|c|c|}
\hline \multirow{2}{*}{ Land-Use } & \multicolumn{2}{|c|}{$\mathbf{2 0 1 3}$} & \multicolumn{2}{c|}{$\mathbf{2 0 2 0}$} \\
\cline { 2 - 5 } & Ha & \% & Ha & \% \\
\hline Forest & 21.53 & 2 & 21.45 & 2 \\
\hline Mixed Garden & 225.4 & 18 & 202.6 & 16 \\
\hline $\begin{array}{c}\text { Agricultural } \\
\text { Land }\end{array}$ & 561.6 & 44 & 597.4 & 46 \\
\hline Built Up Area & 3.77 & 0.3 & 3.77 & 0.3 \\
\hline Open Land & 142.7 & 11 & 56.78 & 4 \\
\hline $\begin{array}{c}\text { Open Land } \\
\text { (Beach) }\end{array}$ & 13.37 & 1 & 17.12 & 1 \\
\hline Settlements & 189.1 & 15 & 213.1 & 17 \\
\hline Livestock & 5.5 & 0.4 & 5.5 & 0.4 \\
\hline Shrubs & 29.41 & 2 & 29.41 & 2 \\
\hline Pond & 26.82 & 2 & 24.59 & 2 \\
\hline Water Body & 66.78 & 5 & 114.2 & 9 \\
\hline Grand Total & 1286 & 100 & 1286 & 100 \\
\hline
\end{tabular}

The distribution of land-use change can be observed in Fig. 3. The points where land-use changes occur are quite spread out throughout the village and not only around JJLS. It indicates that the development of the JJLS does not significantly affect changes in land use around the road foundation. It also can be observed that changes occur in the vicinity of the road, namely changes in open land into settlements, open land into ponds, ponds into open land, and forests into open land.

Land-use changes were mostly found in the west or along the Progo River. It is because the river morphology has dynamic properties according to time and space. This process of change has occurred since the river was formed and still ongoing. The driving factors include erosion and deposition, land use, run-off, the 
presence of tides (backwater), the type of river cliffforming material, and transportation [11].

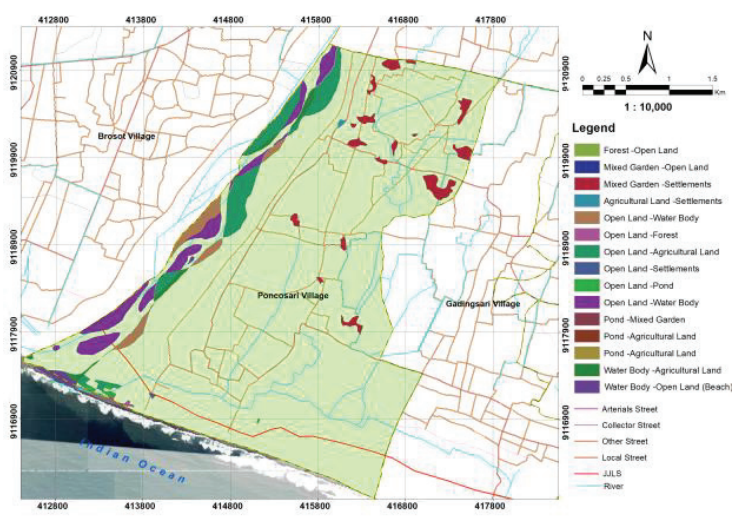

Fig. 3. Map of land-use change in Poncosari Village 2013-2020.

\subsection{Land-use change in Gadingsari Village}

In general, land-use in Gadingsari Village is classified into 10 types. It consists of forest, mixed gardens, agricultural land, built-up land, open land, open land (beach), settlements, livestock, shrubs, and ponds. The total area is $779.64 \mathrm{Ha}$. Table 2. shows that the area of mixed garden land use has shrunk by $6 \%$. Settlements increased by $2 \%$, while the area for agricultural land was fixed during 2013-2020.

Table 2. Percentage of the land-use area in Gadingsari Village.

\begin{tabular}{|c|c|c|c|c|}
\hline \multirow{2}{*}{ Land-Use } & \multicolumn{2}{|c|}{$\mathbf{2 0 1 3}$} & \multicolumn{2}{c|}{$\mathbf{2 0 2 0}$} \\
\cline { 2 - 5 } & Ha & \% & Ha & \% \\
\hline Forest & 37.35 & 5 & 41.57 & 5 \\
\hline Mixed Garden & 200.09 & 26 & 159.34 & 20 \\
\hline Agricultural Land & 312.14 & 40 & 310.69 & 40 \\
\hline Built Up Area & 0 & 0 & 1.43 & 0.2 \\
\hline Open Land & 37.58 & 5 & 30.9 & 4 \\
\hline Open Land (Beach) & 6.43 & 1 & 6.43 & 1 \\
\hline Settlements & 152.98 & 20 & 183.7 & 24 \\
\hline Livestock & 3.95 & 1 & 2.55 & 0,3 \\
\hline Shrubs & 24.41 & 3 & 38.09 & 5 \\
\hline Pond & 4.71 & 1 & 4.94 & 1 \\
\hline Grand Total & 779.64 & 100 & 779.64 & 100 \\
\hline
\end{tabular}

The distribution of land-use change in Gadingsari Village can be observed in Fig. 4. Land-use changes are widespread and vary at several points. There is a pattern where the change from mixed garden to settlement occurs mostly in the western part of Gadingsari Village. This is because it is close to the city center so the demand for land is getting higher. These changes may be driven by the increasing population so that the higher demand for land, especially for residential land. Based on the results of data processing, it proves that the existence of JJLS development has a slight impact on land-use change but the change has less effect on the surrounding environment. This is because the changes that occur are not changes from land to settlements/ built-in land which can become the center of growth.

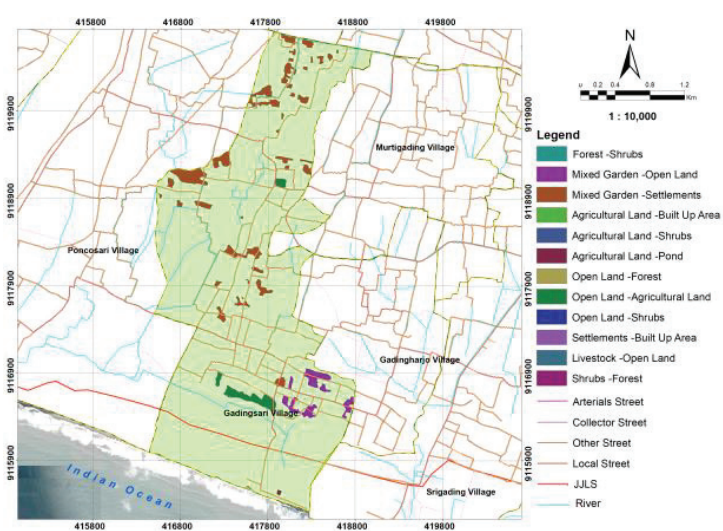

Fig. 4. Map of land-use change in Gadingsari Village 2013-2020.

\subsection{Land-use change in Srigading Village}

The land use in Srigading Village consists of mixed garden land use, agricultural land, built-up land, open land, open land (beach), settlements, shrubs, ponds, and bodies of water. Land uses that experienced an increase in percentage area from 2013 to 2020 were open land (beach) which increased by $1 \%$ and settlements by $2 \%$. Otherwise, the land use that experienced a shrinkage percentage was mixed gardens by $1 \%$ and open land by $1 \%$. Table 3 . shows the land-use change dynamically during 2013-2020.

Table 3. Percentage of the land-use area in Srigading Village

\begin{tabular}{|c|c|c|c|c|}
\hline \multirow{2}{*}{ Land-Use } & \multicolumn{2}{|c|}{2013} & \multicolumn{2}{c|}{ 2020 } \\
\cline { 2 - 5 } & Ha & \% & Ha & \% \\
\hline Mixed Garden & 84.72 & 11 & 77.38 & 10 \\
\hline Agricultural Land & 452.48 & 58 & 449.02 & 58 \\
\hline Open Land & 15.69 & 2 & 11.01 & 1 \\
\hline Open Land (Beach) & 19.36 & 2 & 20.84 & 3 \\
\hline Settlements & 179.01 & 23 & 191.86 & 25 \\
\hline Livestock & 4.4 & 1 & 4.4 & 1 \\
\hline Shrubs & 3.24 & 0.4 & 3.24 & 0.4 \\
\hline Pond & 0.41 & 0.1 & 3.04 & 0.4 \\
\hline Water Body & 18.85 & 2 & 17.37 & 2 \\
\hline Grand Total & 778.16 & 100 & 778.16 & 100 \\
\hline
\end{tabular}

The location of land-use change that occurred in Srigading Village can be observed in Fig. 5. Changes from mixed gardens to settlements occurred in the northern part. The northern part is getting closer to the center of government and economic activity. It makes the community easier to access public facilities such as government offices, markets, and hospitals so that the conversion of agricultural land to non-agricultural land is prevalent in the northern part.

As for the entire JJLS itself, there is no significant change in land use. It is caused by the demand for land 
around JJLS in Bantul Regency is not too high due to roads that are not fully connected. Furthermore, the location around JJLS is quite far from the center of government activities and the village economy.

Another factor that causes the insignificant change in land use is related to the status of land ownership. The status of land ownership around JJLS is divided into the status of the land with ownership rights and the status of the sultan's ground. Sultan Ground island owned by the Ngayogyakarta Hadiningrat Sultanate and its management must obtain official permission from that party. Srigading Village is also one of the villages where shrimp pond relocation destinations. The shrimp ponds are scattered around the Samas Lagoon.

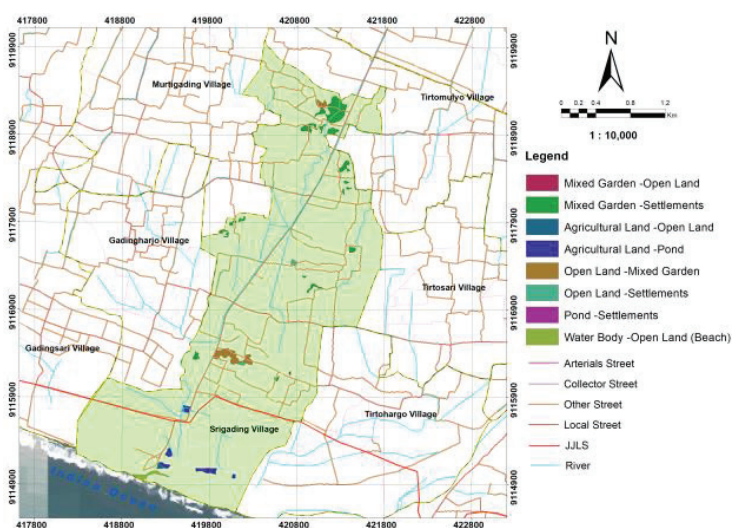

Fig. 5. Map of land-use change in Srigading Village 2013-2020.

\subsection{Land-use change in Tirtohargo Village}

Tirtohargo Village has $388.56 \mathrm{Ha}$ total area of land use. Land use experienced a percentage increase from 2013 to 2020 , namely agricultural land which increased by $2 \%$. Otherwise, land use experienced a percentage decrease, namely open land and water bodies each by $1 \%$. Table 4 . shows the land-use change dynamically during 2013-2020.

Table 4. Percentage of the land-use area in Tirtohargo Village

\begin{tabular}{|c|c|c|c|c|}
\hline \multirow{2}{*}{ Land-Use } & \multicolumn{2}{|c|}{2013} & \multicolumn{2}{c|}{$\mathbf{2 0 2 0}$} \\
\cline { 2 - 5 } & Ha & \% & Ha & \% \\
\hline Mixed Garden & 39.52 & 10 & 37.33 & 10 \\
\hline Agricultural Land & 218.83 & 56 & 224.28 & 58 \\
\hline Open Land & 17.94 & 5 & 16.11 & 4 \\
\hline Open Land (Gisik) & 5.78 & 1 & 5.78 & 1 \\
\hline Settlements & 56.66 & 15 & 58.85 & 15 \\
\hline Livestock & 1.67 & 0 & 1.67 & 0 \\
\hline Water Body & 48.16 & 12 & 44.54 & 11 \\
\hline Grand Total & 388.56 & 100 & 388.56 & 100 \\
\hline
\end{tabular}

The distribution of land-use change locations in Tirtohargo Village can be observed in Fig. 6. The points where land-use change occurs are in the upper eastern and western parts and not only around JJLS. Changes in land use that occur in Tirtohargo Village include mixed gardens into settlements, open land into agricultural land, bodies of water into agricultural land, bodies of water into open land. Land-use change from mixed gardens occurs along the local road in the west.

The conversion of open land to agricultural land occurred in the southern part near the Depok Lagoon. It can be observed that the changes that occur around the JJLS body include water bodies becoming open land. This change of water bodies into open land is likely due to the construction of the Kretek II Bridge which will connect JJLS in the Samas-Sanden area with DepokParangtritis. The plan is that this bridge will be built along 800 meters to facilitate access for residents and is a national strategic project for the development of JJLS. The Kretek II Bridge will later become the entrance to the DIY region from the southern part.

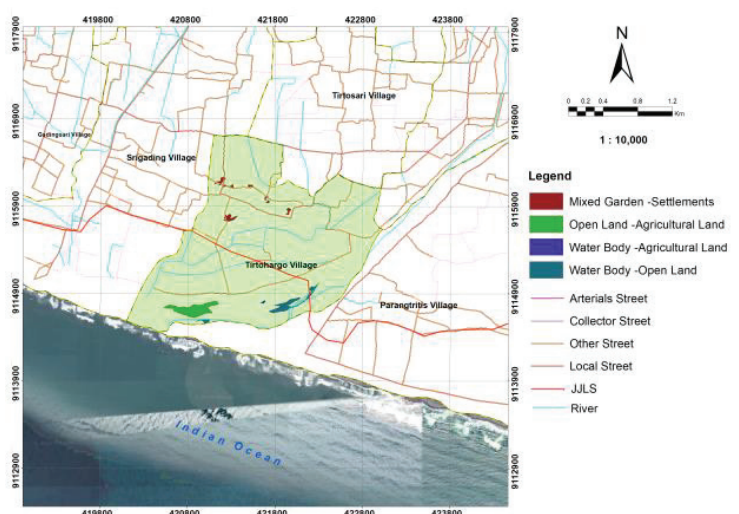

Fig. 6. Map of land-use change in Tirtohargo Village 2013-2020.

\subsection{Land-use change in Parangtritis Village}

Parangtritis Village has extensive land uses in the form of the sand dune. The process of forming a sand dune is influenced by the interaction of wave and wind forces [12]. The sand dunes in Parangtritis Village are of the barchan type [13]. A barchan type is a rare form found in wet tropical climates. Apart from being used as a conservation area, the sand dune is also used as a place of tourism.

In 2020, the type of land use was still the same as in 2013. However, there were depreciation and an increase in the area of land use. Land use that has decreased include mixed gardens, which shrank by $4 \%$, and land use that experienced an increase in area, namely land use in the form of settlements which increased by $1 \%$. Table 5. shows the percentage of land-use change in Parangtritis Village during 2013-2020.

Table 5. Percentage of the land-use area in Parangtritis Village

\begin{tabular}{|c|c|c|c|c|}
\hline \multirow{2}{*}{ Land-Use } & \multicolumn{2}{|c|}{2013} & \multicolumn{2}{c|}{$\mathbf{2 0 2 0}$} \\
\cline { 2 - 5 } & Ha & $\mathbf{\%}$ & Ha & \% \\
\hline Forest & 7.48 & 1 & 7.48 & 1 \\
\hline Mixed Garden & 312.88 & 28 & 269.36 & 24 \\
\hline Agricultural Land & 190.77 & 17 & 190.77 & 17 \\
\hline
\end{tabular}


Continued from Table 5.

\begin{tabular}{|c|c|c|c|c|}
\hline \multirow{2}{*}{ Land-Use } & \multicolumn{2}{|c|}{2013} & \multicolumn{2}{c|}{2020} \\
\cline { 2 - 5 } & Ha & $\mathbf{\%}$ & Ha & $\mathbf{\%}$ \\
\hline Open Land & 0,64 & 0 & 32.9 & 3 \\
\hline $\begin{array}{c}\text { Open Land (Sand } \\
\text { dunes) }\end{array}$ & 354.2 & 32 & 354.2 & 32 \\
\hline Settlements & 150.09 & 13 & 160.07 & 14 \\
\hline Livestock & 62.95 & 6 & 62.95 & 6 \\
\hline Pond & 7.59 & 1 & 7.59 & 1 \\
\hline Water Body & 31.13 & 3 & 31.13 & 3 \\
\hline Grand Total & 1117.09 & 100 & 1117.0 & 100 \\
\hline
\end{tabular}

The distribution of land-use change locations in Parangtritis Village can be observed in Fig. 7. The location points for land-use change occur mostly in the eastern part of the village. This is because the eastern part has a local road, namely Parangtritis Road. Many growth centers will appear around the road so that the demand for land will increase.

Through Fig. 7. it can be observed that the changes that occur around the JJLS agency include mixed gardens into open land and mixed gardens into settlements. Changes from mixed plantations to open land often occur in road segments that are still under construction or not yet connected. The road segment is located in Grogol VIII Hamlet, part of Grogol IX Hamlet, and Grogol X Hamlet. JJLS in Parangtritis Village itself passes through 4 hamlets, were in one of the hamlets, namely in Depok Hamlet, the road conditions are already operating and used by both local people and tourists who traveled in Parangtritis.

The road segment which is still in development planning will later connect Bantul Regency with Gunungkidul Regency and will be called the Parangtritis-Girijati section. The road passes through the hill on the east side of Parangtritis Village and the road design follows the contours of the existing hill. The plan is to build 18 curves so that they will be known as 18 turns [14]. Kelok 18 will become a tourism potential in DIY because it has an attraction in the form of beautiful scenery in the form of beach views. Road users and tourists can stop around the winding section to enjoy the view.

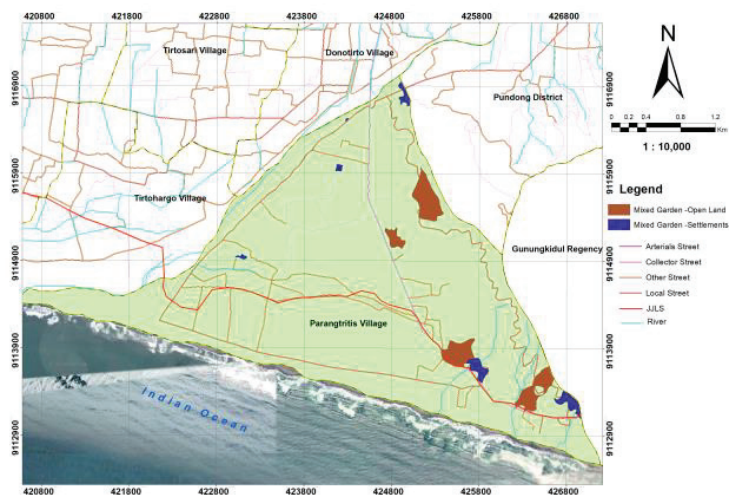

Fig. 7. Map of land-use change in Parangtritis Village 2013-2020.

\section{Conclusion}

In general, the existence of JJLS development in Bantul Regency does not significantly affect the spatial dynamics of land-use changes in each of the villages it passes. The less significant changes in land use are caused by the condition of the JJLS which is not yet fully connected and the status of land ownership which is the Sultan Ground. Most of the changes along the JJLS body occurred in Parangtritis Village and the least occurred in Poncosari Village.

The author expresses her deepest gratitude to RTA-UGM 2021 which has funded this research. And also really appreciate reviewers for suggestions to make this article better. Without all of these supports, this research would not be successful. Hopefully, this article will be useful for the future.

\section{References}

1. W. D. Sasongko, War. Penelit. Perhub. 28, 92 (2018)

2. O. D. Sakarov and G. Kaharap, in Pros. Semin. Nas. XII "Rekayasa Teknol. Ind. Dan Inf. 2017” Sekol. Tinggi Teknol. Nas. Yogyakarta (2017), pp. 453-459

3. I. Chairunnisa, R. Rijanta, and S. Hasanati, J. Bumi Indones. 6, (2017)

4. M. Ja'far, Infrastruktur pro Rakyat: Strategi Investasi Infrastruktur Indonesia Abad 21 (Pustaka Tokoh Bangsa, Yogyakarta, 2007)

5. C. P. Ng, T. H. Law, F. M. Jakarni, and S. Kulanthayan, IOP Conf. Ser. Mater. Sci. Eng. 512, (2019)

6. T. D. Mena, W. P. Tyas, and R. E. Budiati, J. Kesehat. Masy. 7, 156 (2019)

7. M. Alamgir, M. J. Campbell, S. Sloan, M. Goosem, G. R. Clements, M. I. Mahmoud, and W. F. Laurance, Curr. Biol. 27, R1130 (2017)

8. L. Prapti, E. Suryawardana, and D. Triyani, J. Din. Sos. Budaya 17, 82 (2015)

9. H. S. Yunus, Metodologi Penelitian Wilayah Kontemporer (Pustaka Pelajar, Yogyakarta, 2010)

10. B. B. Wiyono, Statistik Pendidikan: Buku Bahan Ajar Mata Kuliah Statistik (FIP UM, Malang, 2001)

11. R. '. Kurniawan, S. '. Sutikno, and B. '. Sujatmoko, J. Online Mhs. Fak. Tek. Univ. Riau 4, 1 (2017)

12. H. D. . Wijayanti and F. Abubakar, Pros. Semin. Nas. XI Rekayasa Teknol. Ind. Dan Inf. 201650 (2016)

13. Sunarto, Geomorfologi Dan Kontribusinya Dalam Pelestarian Pesisir Bergumuk Pasir Aeolian Dari Ancaman Bencana Agrogenik Dan Urbanogenik (Fakultas Geografi. Universitas Gadjah Mada., Yogyakarta, 2014)

14. A. Yulianto, J. Media Wisata 16, 1689 (2018) 